\title{
Intracellular galectins in cancer cells: Potential new targets for therapy (Review)
}

\author{
MARIA C. VLADOIU, MARILYNE LABRIE and YVES ST-PIERRE \\ INRS-Institut Armand-Frappier, Laval, QC H7V 1B7, Canada
}

Received November 1, 2013; Accepted December 2, 2013

DOI: $10.3892 / \mathrm{ijo} .2014 .2267$

\begin{abstract}
Dysregulation of galectin expression is frequently observed in cancer tissues. Such an abnormal expression pattern often correlates with aggressiveness and relapse in many types of cancer. Because galectins have the ability to modulate functions that are important for cell survival, migration and metastasis, they also represent attractive targets for cancer therapy. This has been well-exploited for extracellular galectins, which bind glycoconjugates expressed on the surface of cancer cells. Although the existence of intracellular functions of galectins has been known for many years, an increasing number of studies indicate that these proteins can also alter tumor progression through their interaction with intracellular ligands. In fact, in some instances, the interactions of galectins with their intracellular ligands seem to occur independently of their carbohydrate recognition domain. Such findings call for a change in the basic assumptions, or paradigms, concerning the activity of galectins in cancer and may force us to revisit our strategies to develop galectin antagonists for the treatment of cancer.
\end{abstract}

\section{Contents}

1. Introduction

2. Where do we find galectins inside the cells?

3. Intracellular functions of galectins in cancer

4. CRD-independent functions for intracellular galectins?

\section{Introduction}

Galectins represent a family of evolutionarily conserved animal lectins that are widely distributed from lower invertebrates to higher vertebrates. They were initially described

Correspondence to: Professor Yves St-Pierre, INRS-Institut Armand-Frappier, University of Quebec, 531 Boul. Des Prairies, Laval, QC H7V 1B7, Canada

E-mail: yves.st-pierre@iaf.inrs.ca

Key words: galectin, cancer, subcellular localization in the electric eel, Electrophorus electricus, as low molecular weight, $\beta$-galactoside binding proteins (1). Since then, galectins have been numbered according to the order of their discovery. The 15 family members are now classified according to their structure and number of carbohydrate recognition domain (CRD). The prototype subfamily of galectins (galectin-1, $-2,-5,-7,-10,-11,-13,-14$ and -15 ) consists of a single CRD with a short $\mathrm{N}$-terminal sequence. The tandem-repeat type subfamily (galectin-4, -6, -8, -9 and -12) has two non-identical CRDs joined by a short linker peptide sequence. There is also a chimerical form of galectin (galectin-3) that contains one CRD connected to a non-lectin domain.

One of the first clues that galectins were involved in cancer was published more than 25 years ago when it was observed that they were differently regulated in normal and cancer tissues. Since then, a large number of studies have focused on the role of galectins in cancer and excellent reviews on the role of galectins have been published (2-5). Historically, studies on the role of galectins in cancer have mostly focused on their ability to bind membrane-anchored cell surface receptors via their CRD. Their dimeric form (or multimeric in the case of galectin-3) induces crosslinking of the receptors and formation of a lattice that triggers a cascade of transmembrane signaling events. For example, binding of galectin-3 protects EGF and TGF- $\beta$ receptors from negative regulation via constitutive endocytosis and increases sensitivity of tumor cells to growth factors (6). Binding to cell surface receptors can also induce apoptosis. This is particularly relevant in the case of galectin-1, which is capable of inducing apoptosis of T-cells and potentially create an immunosuppressive tumor microenvironment (7). Alternatively, binding to cell surface receptors can facilitate intercellular adhesion (to promote homo- and heterotypic aggregation) or adhesion of tumor cells to extracellular matrix proteins. Exhaustive efforts have thus been deployed for the identification of highly selective and potent galectin inhibitors. Despite decades of research, the progression in this field has been relatively slow. In most cases, these inhibitors are peptides or high molecular weight, naturally occurring polysaccharides that are used to specifically block the binding of extracellular galectins to carbohydrate structures on cell surface receptors. While targeting extracellular galectins is warranted, such inhibitors are largely if not completely ineffective at targeting intracellular galectins. Indeed, most galectins preferentially exist in intracellular 
compartments, consistent with the fact that they do not harbor a signal sequence and are transported outside the cells via a non-classical secretory pathway, possibly via galectin-rich vesicles or exosomes. A better understanding of their intracellular functions in cancer cells is thus critical to help develop new anticancer therapies directed at these proteins.

\section{Where do we find galectins inside the cells?}

The answer to this question is rather simple: almost anywhere (Fig. 1). They can be detected in various intracellular compartments of both normal and cancerous cells. Frequently, modifications in the subcellular localization occur when cells undergo cell-transformation into malignant phenotypes (4). It is noteworthy to mention that galectins expression is also modulated during some of these cell transformation processes, hence their presence/absence in those subcellular localizations is not exclusive to protein translocation (8). Up to now, however, our knowledge of intracellular galectins has mostly been obtained while studying galectin-3. As we gain more and more knowledge on other members of the galectin family, we find overwhelming evidence that most if not all galectins are often expressed inside the cells. Here we describe the intracellular localization of various galectins with their respective cancer tissues and/or cell lines (Table I).

Galectin-1 is observed in the nuclear compartment of transfected HeLa cells (9) and the inner plasma membrane of colorectal adenocarcinoma cells (HCT116) (10). Moreover, its presence is also seen in the cytosol of neuroblastoma and small cell lung carcinoma tissues, testicular interstitial and cervical carcinoma cell lines (MA-10 and HeLa), hypopharyngeal (HSCCs) and laryngeal (LSCCs) squamous cell carcinoma tissues, human melanoma cell lines (A375 and A2058) and colorectal cancer tissues including adenomas, carcinomas and metastases from patients (9,11-15). Although fewer studies have been conducted on galectin-2, the available data indicate its presence in the nucleus of genetically engineered human colon cancer cells that have ectopic stable expression (16) in addition to gastric carcinoma tissues, epidermoid carcinoma, osteosarcoma and glioblastoma cell lines (A-431, U-2 OS and U-251MG) $(17,18)$. Its presence has also been reported in the cytosol of gastric carcinoma tissues and in mitochondria of epidermoid carcinoma, osteosarcoma and glioblastoma cell lines (A-431, U-2 OS and $\mathrm{U}-251 \mathrm{MG})(17,18)$. In the case of galectin-3, one of the most investigated members of the galectin family, its presence is detected in the nucleus of aggressive endometrial adenocarcinoma, melanoma cell lines, malignant thyroid carcinomas (follicular adenoma, Hürthle cell adenoma and papillary carcinoma) (19-21). Galectin-3 is also found in the cytosol of colonic adenomas/carcinomas tissues, follicular/papillary thyroid carcinomas, endometrial adenocarcinoma, human melanoma cell lines (M1Do and M4Be), malignant thyroid carcinoma (follicular adenoma, Hürthle cell adenoma and papillary carcinoma) and in tongue squamous cell carcinoma tissues (19-24). Additionally, galectin-3 is found in the mitochondria of colorectal adenocarcinoma cell line (SNU-769B), in endosomal compartments of breast adenocarcinoma cell line (SKBR3), and in apical membrane regions of human colon adenocarcinoma cell lines (T84 and HCT116) (10,2527). Galectin-4 is detected in the cytosol of human breast ductal carcinoma tissues $(28,29)$ and pancreatic adenocarcinoma cell line (Pa-Tu-8988S) (29) as well as inside the basal plasma membrane of human colon adenocarcinoma cells (T84) (27). Galectin-7, which has recently attracted more interest in cancer because its preferential expression in epithelial tissues and carcinomas, is seen in the nucleus of many cancer cells, including hypopharyngeal (HSCCs) and laryngeal (LSCCs) squamous cell carcinomas tissues, colon carcinoma cells (DLD-1), cervical adenocarcinoma (HeLa), epithelial ovarian cancer tissues and oral epithelial dysplasia tissues (13,30-32). Galectin-7 is also observed in the cytosol of the colon carcinoma cell line DLD-1, cervical adenocarcinoma cells (HeLa), epithelial ovarian cancer and oral epithelial dysplasia tissues (17,30-32). Like galectin-3, it is also detected in mitochondrial fractions, most notably in the case of human colorectal carcinoma and cervical adenocarcinoma cell lines (HCT116, HeLa) and the HaCaT keratinocyte cell line (33). Galectin-8 expression is detected in the cytosol, nucleus and mitochondria of tumor-associated epithelial cells from human prostate and breast tissues (34). Intracellular galectin-9 is observed in the cytosol of human melanoma cell lines (MM-BP and MM-RU) and the MCF-7 breast carcinoma cell line $(35,36)$. Galectin-10 is observed in the nuclei and cytosol of epidermoid carcinoma cells and in the cytoplasmic compartments of glioblastoma and osteosarcoma. In the human promyelocytic leukemia HL-60 cell line, it is found in the nucleus, cytosol and mitochondria (37) while its localization is associated with the inner plasma membrane of many glioblastoma cell lines (A-431, U-2 OS and U-251MG) (17). Galectin-12 is observed in the cytosol and mitochondria of osteosarcoma and glioblastoma cell lines (U-2 OS and U-251MG) (17).

Although there are no reports yet that other galectins are present inside cancer cells, there are indications that this may well be the case given their presence inside normal cells. For example, galectin-12, a close structural homolog of galectin-7, has been found in the nucleus and mitochondrial fractions of adipocytes (38-40). The fact that galectin-12-deficient mice have abnormal mitochondrial activity is particularly interesting considering the key role of mitochondria in energy metabolism of cancer cells $(41,42)$. Galectin-10 is also found inside human regulatory $\mathrm{T}$-cells and other inflammatory cells (43) while galectin-13 is found in the perinuclear area of syncytiotrophoblasts (44). Computational predictions of where galectins resides in a cell show that it is logical to assume that many galectins will be present within several intracellular compartments. For example, using pSORT, a commonly used tool to predict intracellular localization of proteins, we found that all galectins have a strong preference for cytoplasmic, nuclear and mitochondrial compartments (Table II) $(45,46)$. We have obtained similar results using other computational tools (unpublished data).

\section{Intracellular functions of galectins in cancer}

The main challenge in studying the galectin functions in neoplasms remains their opposing functions in tumor progression. Depending on the type of cancer, one galectin 
Table I. Intracellular localization of galectins in different cancers.

\begin{tabular}{|c|c|c|c|}
\hline Localization & Galectin & Cancer cell line/tissue from patients & (Refs.) \\
\hline \multirow[t]{14}{*}{ Nuclear } & Galectin-1 & Cervical adenocarcinoma & (9) \\
\hline & Galectin-2 & Colorectal carcinoma & $(16)$ \\
\hline & & Epidermoid carcinoma, osteosarcoma and glioblastoma & (17) \\
\hline & & Gastric carcinoma & $(18)$ \\
\hline & Galectin-3 & Adenocarcinoma of the endometrium & (19) \\
\hline & & Melanoma & $(20)$ \\
\hline & & Thyroid carcinoma (follicular/Hürthle cell/papillary) & $(21)$ \\
\hline & Galectin-7 & Hypopharyngeal/laryngeal squamous cell carcinoma & (13) \\
\hline & & Colorectal carcinoma and cervical adenocarcinoma & $(30)$ \\
\hline & & Epithelial ovarian cancer & $(31)$ \\
\hline & & Oral epithelial dysplasia & $(32)$ \\
\hline & Galectin-8 & Tumor-associated epithelial cells from prostate and breast carcinoma & $(34)$ \\
\hline & Galectin-10 & Epidermoid carcinoma & $(17)$ \\
\hline & & Human promyelocytic leukemia (HL-60) & $(37)$ \\
\hline \multirow[t]{25}{*}{ Cytoplasmic } & Galectin-1 & Cervical adenocarcinoma & $(9)$ \\
\hline & & Neuroblastoma and small cell lung carcinoma & (11) \\
\hline & & Testicular (interstitial cell) carcinoma & $(12)$ \\
\hline & & Hypopharyngeal/laryngeal squamous cell carcinoma & (13) \\
\hline & & Melanoma & (14) \\
\hline & & Colorectal carcinoma & $(15)$ \\
\hline & Galectin-2 & Gastric carcinoma & $(18)$ \\
\hline & Galectin-3 & Colorectal adenoma and carcinoma & $(22)$ \\
\hline & & Follicular and papillary thyroid carcinoma & (23) \\
\hline & & Adenocarcinoma of the endometrium & (19) \\
\hline & & Melanoma & $(20)$ \\
\hline & & Thyroid carcinoma (follicular/ Hürthle cell/papillary) & $(21)$ \\
\hline & & Squamous cell carcinoma of the tongue & (24) \\
\hline & Galectin-4 & Ductal breast carcinoma & $(28)$ \\
\hline & & Pancreatic adenocarcinoma & (29) \\
\hline & Galectin-7 & Colon carcinoma and cervical adenocarcinoma & $(30)$ \\
\hline & & Epithelial ovarian cancer & $(31)$ \\
\hline & & Epidermoid carcinoma and osteosarcoma & $(17)$ \\
\hline & & Oral epithelial dysplasia & $(32)$ \\
\hline & Galectin-8 & Tumor-associated epithelial cell from prostate and breast carcinoma & (34) \\
\hline & Galectin-9 & Melanoma & $(35)$ \\
\hline & & Breast carcinoma & $(36)$ \\
\hline & Galectin-10 & Epidermoid carcinoma and glioblastoma & $(17)$ \\
\hline & & Human promyelocytic leukemia (HL-60) & $(37)$ \\
\hline & Galectin-12 & Osteosarcoma and glioblastoma & $(17)$ \\
\hline \multirow[t]{6}{*}{ Mitochondrial } & Galectin-2 & Epidermoid carcinoma, osteosarcoma and glioblastoma & $(17)$ \\
\hline & Galectin-3 & Colorectal adenocarcinoma & $(25)$ \\
\hline & Galectin-7 & Colorectal carcinoma and cervical adenocarcinoma & $(33)$ \\
\hline & Galectin-8 & Tumor-associated epithelial cell from prostate and breast carcinoma & (34) \\
\hline & Galectin-10 & Human promyelocytic leukemia (HL-60) & $(37)$ \\
\hline & Galectin-12 & Osteosarcoma and glioblastoma & $(17)$ \\
\hline $\begin{array}{l}\text { Endosomal } \\
\text { compartments }\end{array}$ & Galectin-3 & Breast adenocarcinoma & $(26)$ \\
\hline \multirow{4}{*}{$\begin{array}{l}\text { Plasma } \\
\text { membrane }\end{array}$} & Galectin-1 & Colorectal adenocarcinoma & $(10)$ \\
\hline & Galectin-3 & Colorectal adenocarcinoma & $(10,27)$ \\
\hline & Galectin-4 & Colorectal adenocarcinoma & $(27)$ \\
\hline & Galectin-10 & Epidermoid carcinoma, osteosarcoma and glioblastoma & $(17)$ \\
\hline
\end{tabular}




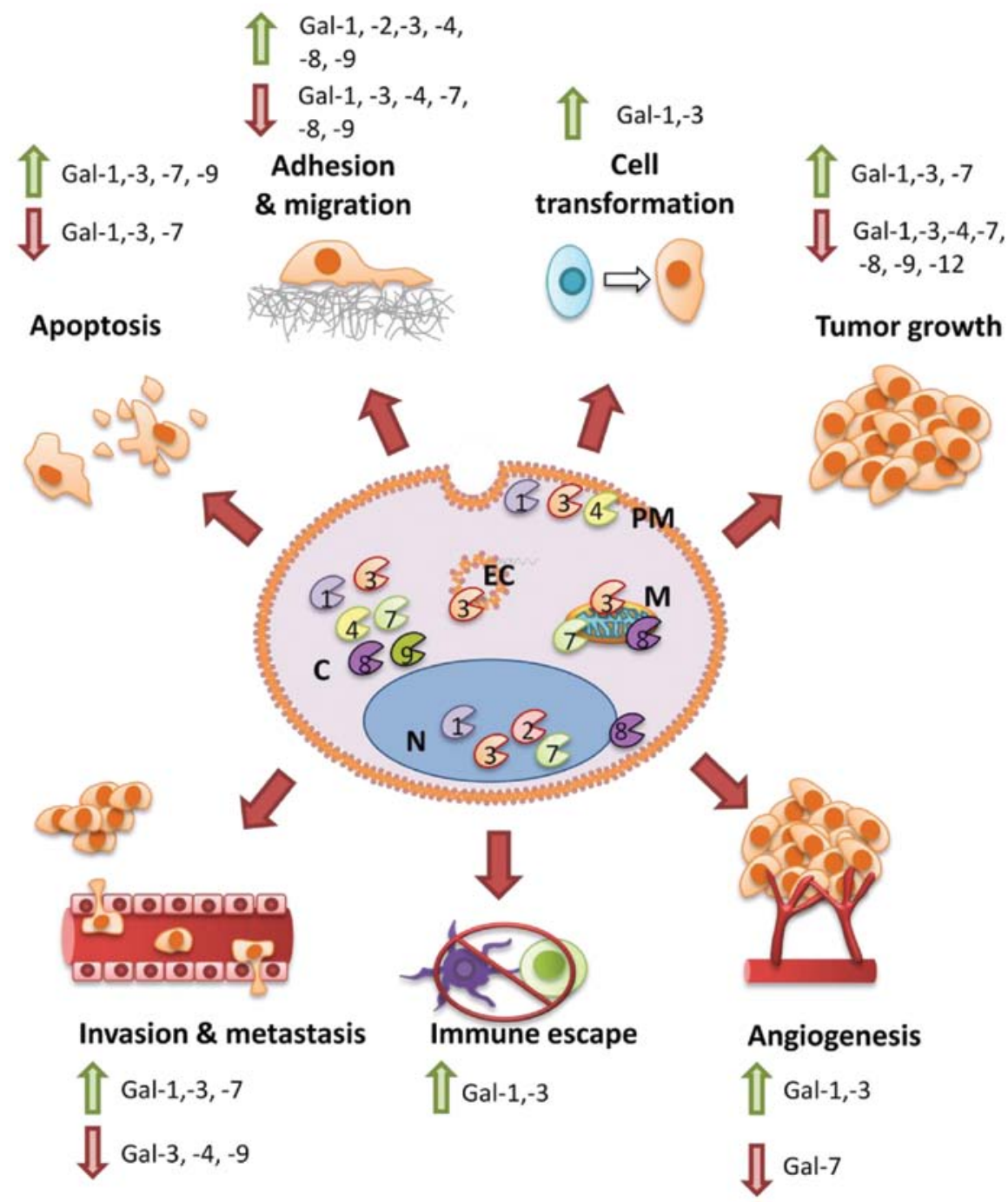

Figure 1. Pro- and anti-tumoral functions of galectins in cancer. Galectins are found in the cytoplasm (C), mitochondria (M), nucleus (N), endosomal compartments (EC) and inner plasma membrane (PM). They are capable of modulating many aspects of tumor progression such as cell adhesion and migration, immune escape, cell transformation, apoptosis, angiogenesis, tumor growth, invasion and metastasis.

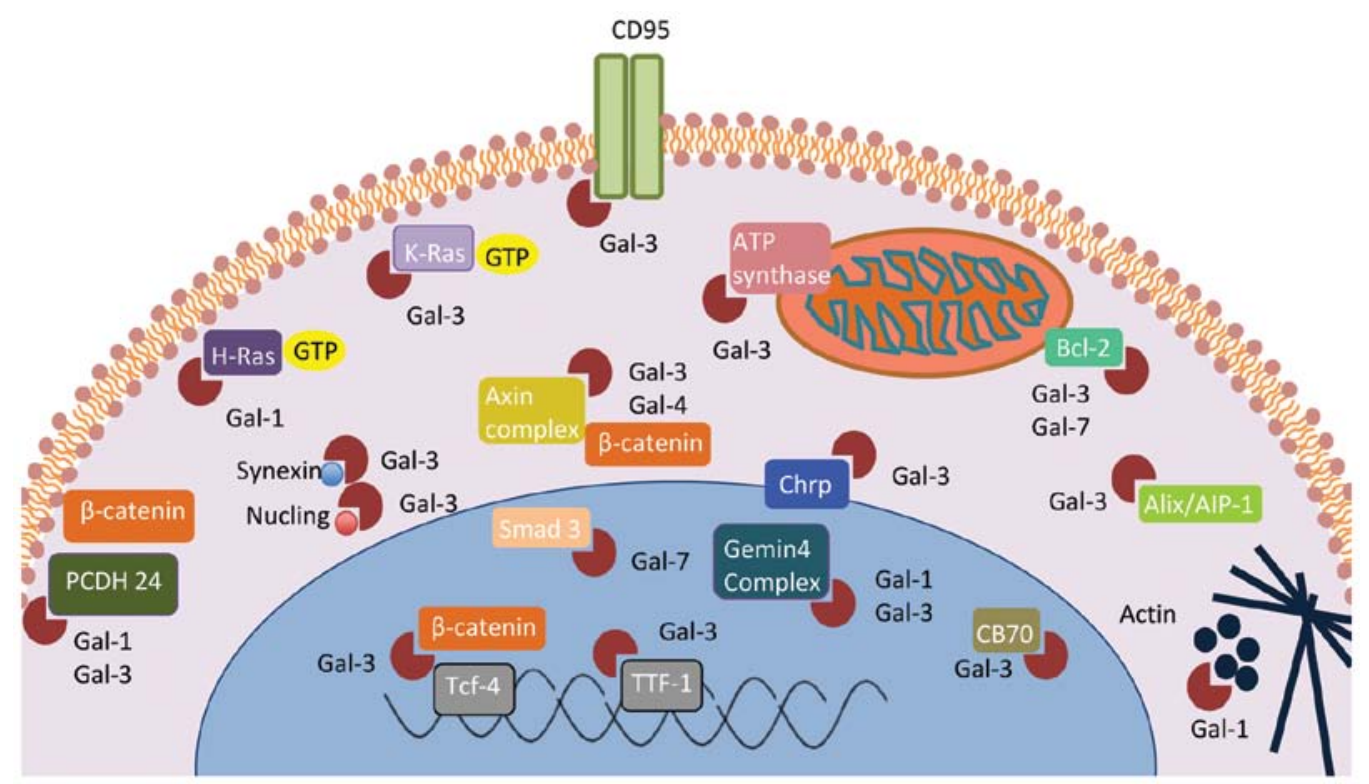

Figure 2. Intracellular binding partners of various galectins. Galectins have numerous binding partners with respect to their inner compartmentalization. 
Table II. Predicted intracellular localization of galectins.

\begin{tabular}{|c|c|c|c|c|c|c|c|c|c|c|}
\hline \multirow{2}{*}{$\begin{array}{l}\text { Cellular } \\
\text { compartment }\end{array}$} & \multicolumn{10}{|c|}{ Galectin $(\%)$} \\
\hline & 1 & 2 & 3 & 4 & 7 & 8 & 9 & 10 & 12 & 13 \\
\hline Cytoplasmic & 65 & 52 & 26 & 65 & 65 & 70 & 65 & 52 & 39 & 61 \\
\hline Nuclear & 22 & 26 & 48 & 17 & 17 & 17 & 17 & 13 & 13 & 17 \\
\hline Mitochondrial & 4 & 9 & 9 & 13 & 17 & 9 & 4 & 4.3 & 44 & 13 \\
\hline ER & 4 & - & - & - & - & 4 & 4 & - & - & 4 \\
\hline VSS & 4 & - & - & 4 & - & - & 4 & - & - & - \\
\hline Vacuolar & - & 4 & - & - & - & - & - & - & - & 4 \\
\hline Cytoskeletal & - & 4 & - & - & - & - & - & 22 & 4.3 & - \\
\hline Peroxisomal & - & 4 & - & - & - & - & - & 9 & - & - \\
\hline
\end{tabular}

ER, endoplasmic reticulum; VSS, vesicles of secretory system.

can either have pro/antitumoral properties $(5,47,48)$ (Fig. 1). This characteristic of galectins can be explained by the large diversity of binding partners (Fig. 2) and by the expression pattern of these partners, which varies contingent to the cell type. Another proposed hypothesis supporting the dual functionalities of galectins in cancer is based on the distinct compartmentalization of the proteins within the cells. In fact, it was shown that intracellular localization of galectins differs according to the cell type and tumor progression stage. Supporting this hypothesis, Califice et al (47) demonstrated that overexpression of galectin-3 in LnCap prostate cancer cells in the cytoplasm induces invasion behavior, anchorage-independant growth, tumor growth and angiogenesis and reduces apoptosis, while nuclear overexpression results in the opposite biological activities. Hence, it is of great interest to take a closer look at the intracellular localization of these galectins and the impact it has on their biological functions with regards to cancer progression. Here, we discuss the main findings on the possible roles of intracellular galectins in cancer. A detailed report of their functions and their putative ligands is found in Tables III and IV.

Cell transformation. A positive correlation between the expression of galectin-1 and -3 and malignant transformation has been established using different cellular models (49-51). Although the mechanisms involved are not completely clear, it potentially involves interactions with membrane-bound H-Ras and K-Ras (52-54). Interestingly, Ras-transformed NIH-3T3 cells have increased expression of galectin-1 and galectin-3 compared to control cells (55). This induction is not necessarily a consequence of Ras pathway activation but rather a secondary effect of cell transformation. Hebert et al demonstrated that Ras transfected cells that have a transformed phenotype, express galectin-3 while Ras transfected cells that have not achieved cell transformation do not (56). Another possibility for galectin-induced malignant transformation might be via their association with the spliceosome. Indeed, galectin-1 and -3 are found in Gemin4 (C50)/SMN/Gemin2 complex and play an important role in spliceosome assembly (57). This association suggests that those galectins might regulate the processing of pre-mRNA during malignant transformation.
Apoptosis. Apoptosis regulation by galectins is probably one of their most studied intracellular functions. Several studies have shown that galectins either positively or negatively regulate apoptosis in various cancer cell models. Galectin-1 for example, increases apoptosis of LnCap prostate cancer cells, CoLo201 colon cancer cells, Leydig tumor cells and B-cell lymphomas (12,58-61). Conversely, it reduces apoptosis in gliomas, cervical and lung cancer (62-64). Galectin-3 has also been shown to modulate apoptosis. In myeloid leukemia, neuroblastoma, colorectal, breast, prostate, thyroid, bladder, pancreatic, gastric and some B-cell lymphoma cancer cells it has been shown to have anti-apoptotic functions (47,65-80). In contrast, it seems to induce apoptosis in other B-cell lymphomas (81). Galectin-7 displays a dual functionality in apoptosis as well since it reduces chemosensitivity in melanomas, breast and lymphoid cancer cells, yet it sensitizes colon, urothelial and cervical cancer cells to cell death (82-87). This role of galectin-7 in melanoma cells is clearly distinct from that of galecin-9 which rather promotes death of melanoma cells $(35,88)$.

The underlying mechanisms of galectin's regulation of apoptosis are not fully understood. Nonetheless, many binding partners implicated in cell fate have been identified. Galectin-3 and -7 have been shown to interact in vitro and in vivo with the anti-apoptotic B-cell lymphoma-2 (Bcl-2) protein $(33,89,90)$. The domain of galectin-7 protein implicated in this binding has not yet been identified. Still, the NWGR motif present at the N-terminus of galectin-3 protein shows a strong homology with the BH1 motif of Bcl-2, which appears to be essential for its anti-apoptotic functions (90). Due to a strong homology between the different pro- and anti-apoptotic members of the Bcl-2 family, galectins might also be able to interact with other members of the family. The modulation of either their stability or their localization would explain the dual role of galectins in apoptosis. The members of the Bcl-2 family are probably not the only galectin-binding partners implicated in apoptosis regulation. Synexin, a calcium and phospholipid-binding protein has been shown to drive the perinuclear translocation of galectin-3, which is essential to its anti-apoptotic function (91). Galectin-3 also interacts with the intracellular domain of the CD95 receptor, also known as FAS receptor 
Table III. Intracellular functions of galectins in different cancers.

\begin{tabular}{|c|c|c|c|}
\hline Galectin & Cancer type & Effect & (Refs.) \\
\hline \multirow[t]{14}{*}{ Galectin-1 } & Thyroid & Expression associated with malignant transformation & $(50,157)$ \\
\hline & Prostate & $\begin{array}{l}\text { Increases adhesion, reduces growth rate and } \\
\text { induces apoptosis of LnCaP cells, provoque tumor } \\
\text { immune evasion and increases tumor vascularization. } \\
\text { Stimulate heterotypic cell-cell adhesion }\end{array}$ & $(58,108,141,158,159)$ \\
\hline & Breast & Induces angiogenesis, tumor immune evasion and progression & $(138,140,160,161)$ \\
\hline & Colorectal & $\begin{array}{l}\text { Associated with malignant progression, reduces cell migration } \\
\text { and induces cell adhesion to ECM and } \\
\text { apoptosis of Colo } 201 \text { cells }\end{array}$ & $(59,110,162)$ \\
\hline & Cervical & Induces radioresistance, proliferation and invasion & $(62,115)$ \\
\hline & Lung & Promote chemoresistance, migration and invasion & $(63,109)$ \\
\hline & Ovarian & Increases proliferation and invasion & $(64)$ \\
\hline & Gliomas & $\begin{array}{l}\text { Increases cell growth, invasion, angiogenesis and } \\
\text { chemotherapy resistance }\end{array}$ & $(51,112,113,137,163-165)$ \\
\hline & B-cell lymphoma & Decreases viability and cell growth & $(60,61)$ \\
\hline & Melanoma & Induces cell aggregation & $(166)$ \\
\hline & Neuroblastoma & Reduces cell growth, induces immunoevasion & $(93,142)$ \\
\hline & Leydig tumor cells & $\begin{array}{l}\text { Regulates positively or negatively cell proliferation } \\
\text { and apoptosis }\end{array}$ & (12) \\
\hline & Hepatic & Increases migration and invasion & $(111)$ \\
\hline & Pancreas & Promotes proliferation, invasion and immune evasion & $(114,142)$ \\
\hline \multirow[t]{2}{*}{ Galectin-2 } & Breast & Increases adhesion & $(116)$ \\
\hline & Colon & Increases adhesion & $(116)$ \\
\hline \multirow[t]{17}{*}{ Galectin-3 } & Colorectal & $\begin{array}{l}\text { Increases metastasis formation, reduces apoptosis and } \\
\text { induces tumor immune evasion }\end{array}$ & $(65,66,125,143,167)$ \\
\hline & Breast & $\begin{array}{l}\text { Induces cell cycle arrest in response to anoikis, increases } \\
\text { adhesion, tumor growth and protects from apoptosis }\end{array}$ & $(67,68,98,168-170)$ \\
\hline & Prostate & $\begin{array}{l}\text { Induces chemoresistance, cell proliferation, angiogenesis, } \\
\text { migration and invasion }\end{array}$ & $(47,69,120,126,171)$ \\
\hline & Thyroid & $\begin{array}{l}\text { Promotes anchorage-independent growth and motility, } \\
\text { regulate cell cycle and cell transformation, } \\
\text { promotes chemoresistance }\end{array}$ & $(70-72,172-174)$ \\
\hline & Liver & Promotes metastasis formation & $(124)$ \\
\hline & Lung & $\begin{array}{l}\text { Increases adhesion, motility, invasion and } \\
\text { tumor immune evasion }\end{array}$ & $(117)$ \\
\hline & B-cell lymphoma & $\begin{array}{l}\text { Increases resistance to fas-induced apoptosis, } \\
\text { chemoresistance or induces apoptosis }\end{array}$ & $(73,81,175,176)$ \\
\hline & Myeloid leukemia & Reduces chemosensitivity & $(74,75)$ \\
\hline & Gliomas & Decreases cell motility and adhesion & $(121)$ \\
\hline & Melanoma & $\begin{array}{l}\text { Increases metastasis formation, tumor immune evasion } \\
\text { and angiogenesis }\end{array}$ & $(122,123,139,177,178)$ \\
\hline & Bladder & Protects cells against TRAIL-induces apoptosis & $(76)$ \\
\hline & Ovarian & Reduces cell proliferation and increases apoptosis resistance & $(179,180)$ \\
\hline & Pancreas & Increases invasion and proliferation, reduces chemosensitivity & $(94,95,181,182)$ \\
\hline & Gastric & Increses cell motility and chemoresistance & $(78,118,119)$ \\
\hline & Tongue & Increases cell proliferation, migration and invasion & $(96,97)$ \\
\hline & Neuroblastoma & Reduces apoptosis & $(79)$ \\
\hline & Renal & Reduces chemosensitivity & $(80)$ \\
\hline \multirow[t]{2}{*}{ Galectin-4 } & Colorectal & $\begin{array}{l}\text { Promotes adhesion, reduces cell migration and motility, } \\
\text { induces cell cycle arrest }\end{array}$ & $(100,101,183)$ \\
\hline & Pancreas & Reduces migration and metastasis formation & (29) \\
\hline
\end{tabular}


Table III. Continued.

\begin{tabular}{|c|c|c|c|}
\hline Galectin & Cancer type & Effect & (Refs.) \\
\hline \multirow[t]{9}{*}{ Galectin-7 } & Breast & Increases invasion, reduces chemosensitivity & $(82)$ \\
\hline & Lymphoma & Increases metastasis formation & $(127-129)$ \\
\hline & Ovarian & Increases cell proliferation & (31) \\
\hline & Neuroblastoma & Reduces cell growth & $(104)$ \\
\hline & Colon & $\begin{array}{l}\text { Increases chemosensitivity and reduces cell growth, } \\
\text { anchorage-independent cell growth and angiogenesis }\end{array}$ & $(83)$ \\
\hline & Urothelial & Increases chemosensitivity & $(85)$ \\
\hline & Cervical & $\begin{array}{l}\text { Increases invasive behavior in vitro, reduces invasion and } \\
\text { chemoresistance }\end{array}$ & $(86,87,130)$ \\
\hline & Melanoma & Increases chemoresistance & $(84)$ \\
\hline & Gastric & Reduces cell proliferation, migration and invasion & $(103)$ \\
\hline \multirow[t]{2}{*}{ Galectin-8 } & Glioblastoma & Stimulates cell migration & $(131)$ \\
\hline & Colon & Reduces tumor growth and cell migration & $(106)$ \\
\hline \multirow[t]{5}{*}{ Galectin-9 } & Melanoma & Induces cell aggregation and apoptosis & $(35,88,136)$ \\
\hline & Breast & Increases cell aggregation and reduces adhesion & $(36)$ \\
\hline & Oral & Increases adhesion & $(132,133)$ \\
\hline & Colon & $\begin{array}{l}\text { Increases adhesion in vitro but reduces metastasis } \\
\text { formation in vivo }\end{array}$ & $(134-136)$ \\
\hline & Myeloma & Reduces cell growth and induces apoptosis & $(105,184)$ \\
\hline \multirow[t]{2}{*}{ Galectin-12 } & Cervical & Reduces cell growth & $(107)$ \\
\hline & T-cell leukemia & Reduces cell growth & $(107)$ \\
\hline
\end{tabular}

(FasR) or apoptosis antigen 1 (APO-1 or APT), leading to opposing apoptogenic mitochondrial activity (92).

Proliferation. Given their role in apoptosis, it is not surprising that galectins play a central role in the control of cell proliferation in tumors. This has been well documented in the case of galectin-1, which reduces proliferation of B-cell lymphomas, neuroblastoma and LnCap prostate cancer cells while it increases cell division of glioma, cervical, ovarian and pancreatic cancer cells $(12,51,58,61,62,64,93)$. A similar case exists for galectin-3, which displays, once more dual functionalities in cell proliferation. For instance, galectin-3 increases proliferation of breast, prostate, pancreatic and tongue tumors $(47,94-98)$. This might be due to the interaction of galectin-3 with the APC/Axin/ $\beta$-catenin complex in the nucleus. This interaction increases the transcriptional activity of Tcf-4 transcription factor and subsequently elevates c-myc and cyclin D1 expression (99). In contrast, cytoplasmic galectin-3, along with galectin-1, bind to protocadherin-24, allowing cytoplasmic localization of $\beta$-catenin, while decreasing Wnt signaling (10). Ectopic expression of galectin- 4 has also been shown to induce cell cycle arrest and to reduce cell migration/motility while sensitizing cells to camptothecin-induced apoptosis in colorectal cancer $(100,101)$. The data from Satelli et al (101) suggest that galectin-4 induces downregulation of $\beta$-catenin, Dvl2, TCF1, TCF4, c-Myc, LRP6 and cyclin D1 expression levels while upregulating p21, p15 Naked 1 and Ephrin B1 $(101,102)$. An interaction between galectin- 4 and APC/Axin/ $\beta$-catenin is also observed that possibly restricts the translocation of the complex to the nucleus. This results in a downregulation of Wnt signaling and a decrease in proliferative potential of colon cancer cells. In contrast, galectin-7 seems to exhibit an increased proliferative activity in ovarian cancer cells, whereas it reduces the proliferation rate of neuroblastomas, colon and gastric cancer cells $(31,103,104)$. Galectin- 8 and -9 have been shown to reduce colon and myelomas tumor growth, respectively $(105,106)$. Galectin-12, for its part, reduces the proliferation of T-leukemia and cervical cancer cells (107). Such contradictory roles for galectins in cell proliferation suggest that extreme precaution must be taken in order to target intracellular galectins in cancer.

Adhesion, migration and invasion. The metastatic behavior of cancer cells is initiated by dysregulation in cell adhesion, migration and invasion abilities. Alterations of interactions between extracellular transmembrane receptors and galectins are often seen in malignancies and late stages of carcinomas. For instance, galectin-1 increases adhesion of colorectal and prostate cancer cells $(59,108)$ and stimulates migration of hepatic and lung cancer cells, while reducing colorectal cell migration (63,109-111). It also increases the invasive behavior of gliomas, lung, ovarian, hepatic, pancreatic and cervical cancer cells $(51,63,64,109,111-115)$. The ability of galectins to increase adhesion and migration has been well documented in the case of galectin- 2 and most notably in the case of galectin-3 (47,67,97,116-120). Specifically, galectin-3 reduces glioma cell migration (121). In general, however, galectin-3 
Table IV. Intracellular ligands of galectins.

\begin{tabular}{|c|c|c|c|c|}
\hline Galectin & Binding partners & $\begin{array}{l}\mathrm{CRD} / \text { non-CRD } \\
\text { binding }\end{array}$ & Effect & (Refs.) \\
\hline \multirow[t]{5}{*}{ Galectin-1 } & H-Ras & & $\begin{array}{l}\text { Increased membrane anchorage of Ras } \\
\text { and GTP bound state resulting in cell } \\
\text { transformation }\end{array}$ & $(52)$ \\
\hline & Gemin4 (C50)/SMN/ & & Supply functional snRNPs to the H/E complex & $(57)$ \\
\hline & Gemin2 complex & & in the pathway of spliceosome assembly & \\
\hline & Protocadherin-24 & & $\begin{array}{l}\text { Localization of } \beta \text {-catenin to the cell membrane } \\
\text { resulting in decreased Wnt signaling }\end{array}$ & $(10)$ \\
\hline & Monomeric actin & CRD & $\begin{array}{l}\text { Polymerization-depolymerization of actin } \\
\text { in platelet aggregation }\end{array}$ & $(185,186)$ \\
\hline \multirow[t]{14}{*}{ Galectin-3 } & ATP synthase & & $\begin{array}{l}\text { Inhibition of ATP synthase activity and } \\
\text { cell cycle progression to G0/G1 phase }\end{array}$ & $(25)$ \\
\hline & Protocadherin-24 & & $\begin{array}{l}\text { Localization } \beta \text {-catenin to the cell membrane } \\
\text { resulting in decreased Wnt signaling }\end{array}$ & $(10)$ \\
\hline & CD95 (APO-1/Fas) & Non-CRD & $\begin{array}{l}\text { Induction of apoptogenic activity } \\
\text { at the mitochondria }\end{array}$ & (92) \\
\hline & Nucling & & Increase sensitivity to apoptosis & (187) \\
\hline & Synexin & & Decrease sensitivity to apoptosis & (91) \\
\hline & CBP70 & CRD & ND & (188) \\
\hline & $\begin{array}{l}\beta \text {-catenin/TCF } \\
\text { complex }\end{array}$ & $\begin{array}{l}\mathrm{NH} 2 \text { and } \\
\mathrm{COOH} \text { termini }\end{array}$ & $\begin{array}{l}\text { Induction of transcriptional activity of Tcf- } 4 \text { with } \\
\text { an increase in c-Myc + cyclin D1 expression }\end{array}$ & (99) \\
\hline & Axin $/ \beta$-catenin $/ \mathrm{APC}$ & $\begin{array}{l}\text { Consensus } \\
\text { sequence } \\
\text { (S92XXXS96) }\end{array}$ & $\begin{array}{l}\text { Promotion GSK-3 } 3 \text {-dependent phosphorylation } \\
\text { of galectin-3/ } \beta \text {-catenin resulting in a decrease } \\
\text { in Wnt signaling }\end{array}$ & (147) \\
\hline & TTF-1 & & $\begin{array}{l}\text { Upregulation of transcriptional activity of TTF- } 1 \\
\text { contributing to cellular proliferation }\end{array}$ & (189) \\
\hline & K-Ras & & $\begin{array}{l}\text { Increase Raf-1/PI3K signaling and attenuated } \\
\text { ERK signaling }\end{array}$ & $(53,54)$ \\
\hline & Bcl-2 & $\begin{array}{l}\text { Non-CRD } \\
\text { (NWGR motif) }\end{array}$ & $\begin{array}{l}\text { Apoptosis-suppressing activity and increase } \\
\text { mitochondrial integrity and decrease } \\
\text { caspase activation }\end{array}$ & $(89,90)$ \\
\hline & Alix/AIP-1 & & $\begin{array}{l}\text { Facilitation of pro-apoptotic signaling } \\
\left(\mathrm{Ca}^{2+} \text { dependent }\right)\end{array}$ & $(190-192)$ \\
\hline & $\begin{array}{l}\text { Gemin4 }(\mathrm{C} 50) / \mathrm{SMN} / \\
\text { Gemin } 2 \text { complex }\end{array}$ & & $\begin{array}{l}\text { Supply functional snRNPs to the H/E complex } \\
\text { in the pathway of spliceosome assembly }\end{array}$ & $(57)$ \\
\hline & Chrp & CRD & $\mathrm{ND}$ & $(193,194)$ \\
\hline Galectin-4 & $\beta$-catenin/APC/Axin & & $\begin{array}{l}\text { Increase Naked } 1 \text { which destabilizes Dsh/Dvl } \\
\text { proteins resulting in a decreased Wnt signaling }\end{array}$ & $(101,102)$ \\
\hline \multirow[t]{2}{*}{ Galectin-7 } & Bcl-2 & & Sensitize mitochondria to apoptosis signals & $(33)$ \\
\hline & Smad 3 & & $\begin{array}{l}\text { Decrease expression of TGF- } \beta \text { responsive genes } \\
\text { resulting in an anti-fibrotic effect on liver tissue }\end{array}$ & $(195)$ \\
\hline
\end{tabular}

is mostly associated with increased invasive behavior in most cancer cell types tested $(94,95,117,122-126)$, supporting the view that targeting this galectin might be a promising avenue for the treatment of many types of cancer. Whether this is also true for other galectins has to be determined. On the contrary, galectin- 4 was found to promote adhesion of colorectal cells and to reduce migration and metastasis formation of colorectal and pancreatic cancer cells (29). Further, conflicting functionalities are once again displayed in the case of galectin-7 dependent on the cell type. Particularly, galectin-7 reduces migration of gastric cancer cells and invasion of urothelial and gastric cancer cells $(85,103)$ while it is associated with increased invasion of other types of cancer, including breast cancer and T-cell lymphoma (82,127-130). Galectin- 8 also seems to have different abilities to modulate migration, most notably in glioblastoma and colon cancer 
cells $(106,131)$. A similar scenario exists for galectin-9, which increases adhesion of melanoma, oral and colon cancer cells, but reduces adhesion of melanoma and breast cancer cells and metastasis formation of colon cancer cells $(35,36,132$ 136). How galectin positively or negatively modulates the invasive behavior of cancer cells remains largely unknown. There are some indications that galectins may increase the secretion of extracellular proteases, remarkably in the case of galectin-7, which induces the upregulation of matrix metalloproteinase-9 (MMP-9) gene expression, possibly through the p38 mitogenic-activated protein kinase (MAPK) $(128,130)$. Unlike apoptosis, however, the identification of the intracellular binding partners that are involved in the modulation of the invasive behavior of cancer cells remains unknown. In contrast, extracellular galectins and their respective binding partners have been fairly well characterized.

Other functions of galectins. Angiogenesis is also among the functions associated with galectin activity. For example, galectin-1 increases glioma, prostate and breast tumor vascularisation $(108,137,138)$. Galectin-3 also increases vascularisation of prostate tumors and melanomas, while galectin-7 reduces angiogenesis of colon tumors $(47,83,139)$. Galectins have been shown to take part in the tumor immune escape. Indeed, galectin-1 promotes immunoevasion of neuroblastoma, prostate, breast and pancreatic cancer cells (140-142). Galectin-3 also increases tumor immune escape of melanomas, colorectal and lung cancer cells $(117,123,143)$. Most studies suggest that extracellular galectins are responsible for these functions. The involvement of intracellular galectins in these processes remains unknown.

\section{CRD-independent functions for intracellular galectins?}

Galectins are primarily known for their ability to bind to glycans containing lactose or $\mathrm{N}$-aceyllactosamine via Van der Walls interactions between the carbohydrate and binding pocket. They have a relatively broad specificity depending on the type and the length of the carbohydrate and the mode of presentation of ligand to the CRD. It is thus logical to assume that inside the cells, they will also preferentially bind to intracellular glycoconjugates, which are abundantly found in the cytosol. There is compelling evidence, however, that galectins might have non-carbohydrate binding partners and functions. CRD-independent functions have been particularly well documented for intracellular galectins (144-146). For example, galectins do interact with Bcl-2 family members via a CRD-independent interaction $(33,85,89,90)$. This galectin/Bcl-2 interaction is important since the balance of activity between pro- and anti-apoptotic signals of members of the Bcl-2 family regulates apoptosis. Other CRD-independent functions of galectins include RNA processing in the nucleus (57) and regulation of cell cycle progression (Wnt signaling?) $(25,99,101,102,147)$. All these galectin functions are independent of their saccharidic binding activities and rather rely on protein-protein interactions. Some galectins, such as galectin-10, harbor very low affinity for galactosides and are believed to act mainly through other specificities, while their CRD binding activity remains debated $(148,149)$. These CRD-independent functions represent a paradigm shift in our understanding of galectin function and the development of galectin-specific antagonists.

A new challenge: studying the redundancy of galectin functions. The existence of redundant or antagonistic functions between galectins is a major concern because these proteins can converge under normal or pathological conditions. The cross-talk between intracellular galectins remains completely unknown although cells often express more than one intracellular galectin. For example, MCF-7 breast cancer cells express galectin-3, -8 and -9 (150). MCF-10 and MDA-MB-468, two other human mammary epithelial cell lines, express both galectin-3 and -7 , but not galectin- 8 or $-9(151,152)$. Moreover, many galectins could be present within the same intracellular compartments. A case in point is the mitochondria, where both galectin-3 and -7 are found. Galectin-12 can also be present in mitochondria and not surprisingly, it seems to be involved in the control of cellular metabolism (38-40). Whether galectins have redundant or opposed functions in the mitochondria is an interesting question given the critical role of cellular metabolism in cancer. A better understanding of the functional redundancy among homologous proteins, which is frequently observed in eukaryotes, is also critical. Such redundancy often occurs in order to increase maintenance of important gene function and to limit losses following mutations/deletions of specific genes (functional compensation). Lessons learned from such studies could also bring important insight into many others fields, from understanding pathologies to general developmental biology.

Future directions. Because of their critical role in cancer, considerable efforts have been directed towards the development of carbohydrate-based inhibitors that would limit the binding of galectins to glycosylated residues on cell surface receptors. For example, GCS-100 is a galectin-3 antagonist with a modified citrus pectin carbohydrate that has been shown to inhibit tumor growth and metastasis in several preclinical models (153-155). Others, like OTX008, a galectin-1 antagonist, act as allosteric CRD-dependent inhibitors following binding to a site distant from the carbohydrate-binding site (156). Nevertheless, despite almost two decades of research, the development of effective galectin antagonists for the treatment of cancer has met with limited success. The emerging evidence that galectins have critical intracellular and CRD-independent functions calls for a refocusing of our efforts on development of new galectin-specific antagonists to modulate apoptosis. Our knowledge of the subcellular localization of galectins will also significantly improve target identification during the drug discovery process. It is thus imperative to better understand the role of intracellular galectins and to provide novel insight into how galectins collaboratively modulate cancer progression from within the cells.

\section{Acknowledgements}

This research was supported by a grant from the National Science and Engineering Research Council of Canada (NSERC). M.L. is supported by a doctoral studentship from the Fonds de la Recherche du Québec-Santé (FRQS). 


\section{References}

1. Levi G and Teichberg VI: Isolation and physicochemical characterization of electrolectin, a beta-D-galactoside binding lectin from the electric organ of Electrophorus electricus. J Biol Chem 256: 5735-5740, 1981.

2. Astorgues-Xerri L, Riveiro ME, Tijeras-Raballand A, et al: Unraveling galectin-1 as a novel therapeutic target for cancer. Cancer Treat Rev: Aug 1, 2013 (Epub ahead of print).

3. Radosavljevic G, Volarevic V, Jovanovic I, et al: The roles of Galectin-3 in autoimmunity and tumor progression. Immunol Res 52: 100-110, 2012.

4. Van den Brule F, Califice $S$ and Castronovo V: Expression of galectins in cancer: a critical review. Glycoconj J 19: 537-542, 2004.

5. Liu FT and Rabinovich GA: Galectins as modulators of tumour progression. Nat Rev Cancer 5: 29-41, 2005.

6. Partridge EA, Le Roy C, Di Guglielmo GM, et al: Regulation of cytokine receptors by Golgi N-glycan processing and endocytosis. Science 306: 120-124, 2004.

7. Perillo NL, Uittenbogaart CH, Nguyen JT and Baum LG: Galectin-1, an endogenous lectin produced by thymic epithelial cells, induces apoptosis of human thymocytes. J Exp Med 185: 1851-1858, 1997.

8. Chiariotti L, Salvatore P, Frunzio R and Bruni CB: Galectin genes: regulation of expression. Glycoconj J 19: 441-449, 2004

9. Vyakarnam A, Lenneman AJ, Lakkides KM, Patterson RJ and Wang JL: A comparative nuclear localization study of galectin-1 with other splicing components. Exp Cell Res 242: 419-428, 1998

10. Ose R, Oharaa O and Nagase T: Galectin- 1 and galectin-3 mediate protocadherin-24-dependent membrane localization of beta-catenin in colon cancer cell line HCT116. Curr Chem Genomics 6: 18-26, 2012.

11. Gabius HJ, Andre S, Gunsenhauser I, et al: Association of galectin-1- but not galectin-3-dependent parameters with proliferation activity in human neuroblastomas and small cell lung carcinomas. Anticancer Res 22: 405-410, 2002.

12. Biron VA, Iglesias MM, Troncoso MF, et al: Galectin-1: biphasic growth regulation of Leydig tumor cells. Glycobiology 16: 810-821, 2006.

13. Saussez S,Decaestecker C,LorfevreF,etal:Increased expression and altered intracellular distribution of adhesion/growthregulatory lectins galectins- 1 and -7 during tumour progression in hypopharyngeal and laryngeal squamous cell carcinomas. Histopathology 52: 483-493, 2008.

14. Van den Brule FA, Buicu C, Baldet M, et al: Galectin-1 modulates human melanoma cell adhesion to laminin. Biochem Biophys Res Commun 209: 760-767, 1995.

15. Sanjuan X, Fernandez PL, Castells A, et al: Differential expression of galectin 3 and galectin 1 in colorectal cancer progression. Gastroenterology 113: 1906-1915, 1997.

16. Dvorankova B, Lacina L, Smetana K Jr, et al: Human galectin-2: nuclear presence in vitro and its modulation by quiescence/ stress factors. Histol Histopathol 23: 167-178, 2008.

17. Uhlen M, Oksvold P, Fagerberg L, et al: Towards a knowledge-based Human Protein Atlas. Nat Biotechnol 28: 1248-1250, 2010.

18. Viaene AN, Petrof I and Sherman SM: Properties of the thalamic projection from the posterior medial nucleus to primary and secondary somatosensory cortices in the mouse. Proc Natl Acad Sci USA 108: 18156-18161, 2011.

19. Van den Brule FA, Buicu C, Berchuck A, et al: Expression of the 67-kD laminin receptor, galectin-1, and galectin-3 in advanced human uterine adenocarcinoma. Hum Pathol 27: 1185-1191, 1996.

20. Mey A, Berthier-Vergnes O, Apoil PA, Dore JF and Revillard JP. Expression of the galactose binding protein Mac-2 by human melanoma cell-lines. Cancer Lett 81: 155-163, 1994.

21. Matesa-Anic D, Moslavac S, Matesa N, Cupic H and Kusic Z: Intensity and distribution of immunohistochemical expression of galectin-3 in thyroid neoplasms. Acta Clin Croat 51: 237-241, 2012.

22. Lotz MM, Andrews CW Jr, Korzelius CA, et al: Decreased expression of Mac-2 (carbohydrate binding protein 35) and loss of its nuclear localization are associated with the neoplastic progression of colon carcinoma. Proc Natl Acad Sci USA 90 3466-3470, 1993.

23. Kawachi K, Matsushita Y, Yonezawa S, et al: Galectin-3 expression in various thyroid neoplasms and its possible role in metastasis formation. Hum Pathol 31: 428-433, 2000.
24. Honjo Y, Inohara H, Akahani S, et al: Expression of cytoplasmic galectin-3 as a prognostic marker in tongue carcinoma. Clin Cancer Res 6: 4635-4640, 2000.

25. Kim DW, Kim KH, Yoo BC, et al: Identification of mitochondrial $\mathrm{F}(1) \mathrm{F}(0)$-ATP synthase interacting with galectin-3 in colon cancer cells. Cancer Sci 99: 1884-1891, 2008.

26. Lepur A, Carlsson MC, Novak R, Dumic J, Nilsson UJ and Leffler H: Galectin-3 endocytosis by carbohydrate independent and dependent pathways in different macrophage like cell types. Biochim Biophys Acta 1820: 804-818, 2012.

27. Huflejt ME, Jordan ET, Gitt MA, Barondes SH and Leffler H: Strikingly different localization of galectin-3 and galectin-4 in human colon adenocarcinoma T84 cells. Galectin-4 is localized at sites of cell adhesion. J Biol Chem 272: 14294-14303, 1997.

28. Huflejt ME and Leffler H: Galectin-4 in normal tissues and cancer. Glycoconj J 20: 247-255, 2004.

29. Belo AI, van der Sar AM, Tefsen B and van Die I: Galectin-4 reduces migration and metastasis formation of pancreatic cancer cells. PLoS One 8: e65957, 2013.

30. Kuwabara I, Kuwabara Y, Yang RY, et al: Galectin-7 (PIG1) exhibits pro-apoptotic function through JNK activation and mitochondrial cytochrome c release. J Biol Chem 277: 3487-3497, 2002.

31. Kim HJ, Jeon HK, Lee JK, et al: Clinical significance of galectin-7 in epithelial ovarian cancer. Anticancer Res 33: $1555-1561,2013$.

32. De Vasconcelos Carvalho M, Pereira Jdos S, Alves PM, Silveira EJ, de Souza LB and Queiroz LM: Alterations in the immunoexpression of galectins-1, -3 and -7 between different grades of oral epithelial dysplasia. J Oral Pathol Med 42: 174-179, 2013.

33. Villeneuve C, Baricault L, Canelle L, et al: Mitochondrial proteomic approach reveals galectin-7 as a novel BCL-2 binding protein in human cells. Mol Biol Cell 22: 999-1013, 2011.

34. Delgado VM, Nugnes LG, Colombo LL, et al: Modulation of endothelial cell migration and angiogenesis: a novel function for the 'tandem-repeat' lectin galectin-8. FASEB J 25: 242-254, 2011.

35. Kageshita T, Kashio Y, Yamauchi A, et al: Possible role of galectin-9 in cell aggregation and apoptosis of human melanoma cell lines and its clinical significance. Int J Cancer 99: 809-816, 2002.

36. Irie A, Yamauchi A, Kontani K, et al: Galectin-9 as a prognostic factor with antimetastatic potential in breast cancer. Clin Cancer Res 11: 2962-2968, 2005.

37. Rousseau C, Muriel MP, Musset M, Botti J and Seve AP. Glycosylated nuclear lectin CBP70 also associated with endoplasmic reticulum and the Golgi apparatus: does the "classic pathway' of glycosylation also apply to nuclear glycoproteins? J Cell Biochem 78: 638-649, 2000.

38. Hotta K, Funahashi T, Matsukawa Y, et al: Galectin-12, an adipose-expressed galectin-like molecule possessing apoptosisinducing activity. J Biol Chem 276: 34089-34097, 2001.

39. Wang JL, Gray RM, Haudek KC and Patterson RJ: Nucleocytoplasmic lectins. Biochim Biophys Acta 1673: 75-93, 2004.

40. Carlsson S, Carlsson MC and Leffler H: Intracellular sorting of galectin- 8 based on carbohydrate fine specificity. Glycobiology 17: 906-912, 2007.

41. Yang RY, Yu L, Graham JL, et al: Ablation of a galectin preferentially expressed in adipocytes increases lipolysis, reduces adiposity, and improves insulin sensitivity in mice. Proc Natl Acad Sci USA 108: 18696-18701, 2011.

42. Baum LG: Burn control, an adipocyte-specific function for galectin-12. Proc Natl Acad Sci USA 108: 18575-18576, 2011.

43. Kubach J, Lutter P, Bopp T, et al: Human $C D 4^{+} \mathrm{CD} 25^{+}$regulatory $\mathrm{T}$ cells: proteome analysis identifies galectin-10 as a novel marker essential for their anergy and suppressive function. Blood 110: 1550-1558, 2007.

44. Than NG, Pick E, Bellyei S, et al: Functional analyses of placental protein 13/galectin-13. Eur J Biochem 271: 1065-1078, 2004.

45. Nakai K and Horton P: PSORT: a program for detecting sorting signals in proteins and predicting their subcellular localization. Trends Biochem Sci 24: 34-36, 1999.

46. Nakai K and Kanehisa M: A knowledge base for predicting protein localization sites in eukaryotic cells. Genomics 14: 897-911, 1992.

47. Califice S, Castronovo V, Bracke $\mathrm{M}$ and van den Brule F: Dual activities of galectin-3 in human prostate cancer: tumor suppression of nuclear galectin-3 vs tumor promotion of cytoplasmic galectin-3. Oncogene 23: 7527-7536, 2004. 
48. St-Pierre Y, Campion CG and Grosset AA: A distinctive role for galectin-7 in cancer? Front Biosci (Landmark Ed) 17: 438-450, 2012.

49. Chiariotti L, Berlingieri MT, De Rosa P, et al: Increased expression of the negative growth factor, galactoside-binding protein, gene in transformed thyroid cells and in human thyroid carcinomas. Oncogene 7: 2507-2511, 1992.

50. Xu XC, el-Naggar AK and Lotan R: Differential expression of galectin-1 and galectin-3 in thyroid tumors. Potential diagnostic implications. Am J Pathol 147: 815-822, 1995.

51. Yamaoka K, Mishima K, Nagashima Y, Asai A, Sanai Y and Kirino T: Expression of galectin-1 mRNA correlates with the malignant potential of human gliomas and expression of antisense galectin-1 inhibits the growth of 9 glioma cells. J Neurosci Res 59: 722-730, 2000.

52. Paz A, Haklai R, Elad-Sfadia G, Ballan E and Kloog Y: Galectin-1 binds oncogenic $\mathrm{H}$-Ras to mediate Ras membrane anchorage and cell transformation. Oncogene 20: 7486-7493, 2001.

53. Elad-Sfadia G, Haklai R, Balan E and Kloog Y: Galectin-3 augments K-Ras activation and triggers a Ras signal that attenuates ERK but not phosphoinositide 3-kinase activity. J Biol Chem 279: 34922-34930, 2004.

54. Shalom-Feuerstein R, Levy R, Makovski V, Raz A and Kloog Y: Galectin-3 regulates RasGRP4-mediated activation of N-Ras and H-Ras. Biochim Biophys Acta 1783: 985-993, 2008.

55. Hebert E and Monsigny M: Galectin-3 mRNA level depends on transformation phenotype in ras-transformed NIH 3T3 cells. Biol Cell 81: 73-76, 1994.

56. Hebert E, Roche AC, Nachtigal $M$ and Monsigny $M$ Transformation but not ras-transfection increases the expression of galectin-3 in human HOS cells. C R Acad Sci III 319: 871-877, 1996

57. Park JW, Voss PG, Grabski S, Wang JL and Patterson RJ: Association of galectin-1 and galectin-3 with Gemin4 in complexes containing the SMN protein. Nucleic Acids Res 29: 3595-3602, 2001.

58. Ellerhorst J, Nguyen T, Cooper DN, Estrov Y, Lotan D and Lotan R: Induction of differentiation and apoptosis in the prostate cancer cell line $\mathrm{LNCaP}$ by sodium butyrate and galectin-1. Int J Oncol 14: 225-232, 1999.

59. Horiguchi N, Arimoto K, Mizutani A, Endo-Ichikawa Y, Nakada H and Taketani S: Galectin-1 induces cell adhesion to the extracellular matrix and apoptosis of non-adherent human colon cancer Colo201 cells. J Biochem 134: 869-874, 2003.

60. Fouillit M, Joubert-Caron R, Poirier F, et al: Regulation of CD45-induced signaling by galectin-1 in Burkitt lymphoma B cells. Glycobiology 10: 413-419, 2000.

61. Poirier F, Bourin P, Bladier D, Joubert-Caron R and Caron M: Effect of 5-azacytidine and galectin-1 on growth and differentiation of the human b lymphoma cell line bl36. Cancer Cell Int 1: $2,2001$.

62. Huang EY, Chen YF, Chen YM, et al: A novel radioresistant mechanism of galectin-1 mediated by H-Ras-dependent pathways in cervical cancer cells. Cell Death Dis 3: e251, 2012.

63. Chung LY, Tang SJ, Sun GH, et al: Galectin-1 promotes lung cancer progression and chemoresistance by upregulating p38 MAPK, ERK, and cyclooxygenase-2. Clin Cancer Res 18: 4037-4047, 2012.

64. Kim HJ, Jeon HK, Cho YJ, et al: High galectin-1 expression correlates with poor prognosis and is involved in epithelial ovarian cancer proliferation and invasion. Eur J Cancer 48 1914-1921, 2012.

65. Mazurek N, Byrd JC, Sun Y, et al: Cell-surface galectin-3 confers resistance to TRAIL by impeding trafficking of death receptors in metastatic colon adenocarcinoma cells. Cell Death Differ 19: 523-533, 2012

66. Shi Y, He B, Kuchenbecker KM, et al: Inhibition of Wnt-2 and galectin-3 synergistically destabilizes beta-catenin and induces apoptosis in human colorectal cancer cells. Int J Cancer 121: $1175-1181,2007$

67. Matarrese P, Fusco O, Tinari N, et al: Galectin-3 overexpression protects from apoptosis by improving cell adhesion properties. Int J Cancer 85: 545-554, 2000.

68. Moon BK, Lee YJ, Battle P, Jessup JM, Raz A and Kim HR Galectin-3 protects human breast carcinoma cells against nitric oxide-induced apoptosis: implication of galectin-3 function during metastasis. Am J Pathol 159: 1055-1060, 2001.

69. Fukumori T, Oka N, Takenaka Y, et al: Galectin-3 regulates mitochondrial stability and antiapoptotic function in response to anticancer drug in prostate cancer. Cancer Res 66: 3114-3119, 2006.
70. Lavra L, Ulivieri A, Rinaldo C, et al: Gal-3 is stimulated by gain-of-function p53 mutations and modulates chemoresistance in anaplastic thyroid carcinomas. J Pathol 218: 66-75, 2009.

71. Lin CI, Whang EE, Abramson MA, et al: Galectin-3 regulates apoptosis and doxorubicin chemoresistance in papillary thyroid cancer cells. Biochem Biophys Res Commun 379: 626-631, 2009.

72. Lin CI, Whang EE, Donner DB, et al: Galectin-3 targeted therapy with a small molecule inhibitor activates apoptosis and enhances both chemosensitivity and radiosensitivity in papillary thyroid cancer. Mol Cancer Res 7: 1655-1662, 2009.

73. Hoyer KK, Pang M, Gui D, et al: An anti-apoptotic role for galectin-3 in diffuse large B-cell lymphomas. Am J Pathol 164: 893-902, 2004

74. Cheng YL, Huang WC, Chen CL, et al: Increased galectin-3 facilitates leukemia cell survival from apoptotic stimuli. Biochem Biophys Res Commun 412: 334-340, 2011.

75. Yamamoto-Sugitani M,Kuroda J, Ashihara E, et al: Galectin-3 (Gal-3) induced by leukemia microenvironment promotes drug resistance and bone marrow lodgment in chronic myelogenous leukemia. Proc Natl Acad Sci USA 108: 17468-17473, 2011.

76. Oka N, Nakahara S, Takenaka Y, et al: Galectin-3 inhibits tumor necrosis factor-related apoptosis-inducing ligand-induced apoptosis by activating Akt in human bladder carcinoma cells. Cancer Res 65: 7546-7553, 2005.

77. Kobayashi T, Shimura T, Yajima T, et al: Transient gene silencing of galectin-3 suppresses pancreatic cancer cell migration and invasion through degradation of beta-catenin. Int J Cancer 129: 2775-2786, 2011.

78. Cheong TC, Shin JY and Chun KH: Silencing of galectin-3 changes the gene expression and augments the sensitivity of gastric cancer cells to chemotherapeutic agents. Cancer Sci 101: 94-102, 2010

79. Veschi V, Petroni M, Cardinali B, et al: Galectin-3 impairment of MYCN-dependent apoptosis-sensitive phenotype is antagonized by nutlin-3 in neuroblastoma cells. PLoS One 7: e49139, 2012.

80. Xu Y, Gu X, Gong M, Guo G, Han K and An R: Galectin-3 inhibition sensitizes human renal cell carcinoma cells to arsenic trioxide treatment. Cancer Biol Ther 14: 897-906, 2013.

81. Suzuki O and Abe M: Cell surface N-glycosylation and sialylation regulate galectin-3-induced apoptosis in human diffuse large B cell lymphoma. Oncol Rep 19: 743-748, 2008.

82. Demers M, Rose AA, Grosset AA, et al: Overexpression of galectin-7, a myoepithelial cell marker, enhances spontaneous metastasis of breast cancer cells. Am J Pathol 176: 3023-3031, 2010.

83. Ueda S, Kuwabara I and Liu FT: Suppression of tumor growth by galectin-7 gene transfer. Cancer Res 64: 5672-5676, 2004.

84. Biron-Pain K, Grosset AA, Poirier F, Gaboury L and St-Pierre Y: Expression and functions of galectin-7 in human and murine melanomas. PLoS One 8: e63307, 2013.

85. Matsui Y, Ueda S, Watanabe J, Kuwabara I, Ogawa O and Nishiyama H: Sensitizing effect of galectin-7 in urothelial cancer to cisplatin through the accumulation of intracellular reactive oxygen species. Cancer Res 67: 1212-1220, 2007.

86. Tsai CJ, Sulman EP, Eifel PJ, et al: Galectin-7 levels predict radiation response in squamous cell carcinoma of the cervix. Gynecol Oncol: Apr 30, 2013 (Epub ahead of print).

87. Zhu H, Wu TC, Chen WQ, et al: Roles of galectin-7 and S100A9 in cervical squamous carcinoma: Clinicopathological and in vitro evidence. Int J Cancer 132: 1051-1059, 2013.

88. Wiersma VR, de Bruyn M, van Ginkel RJ, et al: The glycan-binding protein galectin-9 has direct apoptotic activity toward melanoma cells. J Invest Dermatol 132: 2302-2305, 2012.

89. Yang RY, Hsu DK and Liu FT: Expression of galectin-3 modulates T-cell growth and apoptosis. Proc Natl Acad Sci USA 93: 6737-6742, 1996.

90. Akahani S, Nangia-Makker P, Inohara H, Kim HR and Raz A: Galectin-3: a novel antiapoptotic molecule with a functional BH1 (NWGR) domain of Bcl-2 family. Cancer Res 57: 5272-5276, 1997.

91. Dumic J, Dabelic S and Flogel M: Galectin-3: an open-ended story. Biochim Biophys Acta 1760: 616-635, 2006.

92. Fukumori T, Takenaka Y, Oka N, et al: Endogenous galectin-3 determines the routing of CD95 apoptotic signaling pathways. Cancer Res 64: 3376-3379, 2004.

93. Kopitz J, von Reitzenstein C, Andre S, et al: Negative regulation of neuroblastoma cell growth by carbohydrate-dependent surface binding of galectin-1 and functional divergence from galectin-3. J Biol Chem 276: 35917-35923, 2001. 
94. Jiang HB, Xu M and Wang XP: Pancreatic stellate cells promote proliferation and invasiveness of human pancreatic cancer cells via galectin-3. World J Gastroenterol 14: 2023-2028, 2008.

95. Song S, Ji B, Ramachandran V, et al: Overexpressed galectin-3 in pancreatic cancer induces cell proliferation and invasion by binding Ras and activating Ras signaling. PLoS One 7: e42699, 2012.

96. Wang LP, Chen SW, Zhuang SM, Li H and Song M: Galectin-3 accelerates the progression of oral tongue squamous cell carcinoma via a Wnt/beta-catenin-dependent pathway. Pathol Oncol Res 19: 461-474, 2013.

97. Zhang D, Chen ZG, Liu SH, et al: Galectin-3 gene silencing inhibits migration and invasion of human tongue cancer cells in vitro via downregulating beta-catenin. Acta Pharmacol Sin 34: 176-184, 2013.

98. Kim HR, Lin HM, Biliran H and Raz A: Cell cycle arrest and inhibition of anoikis by galectin-3 in human breast epithelial cells. Cancer Res 59: 4148-4154, 1999.

99. Shimura T, Takenaka Y, Tsutsumi S, Hogan V, Kikuchi A and Raz A: Galectin-3, a novel binding partner of beta-catenin. Cancer Res 64: 6363-6367, 2004.

100. Kim SW, Park KC, Jeon SM, et al: Abrogation of galectin-4 expression promotes tumorigenesis in colorectal cancer. Cell Oncol (Dordr) 36: 169-178, 2013.

101. Satelli A, Rao PS, Thirumala S and Rao US: Galectin-4 functions as a tumor suppressor of human colorectal cancer. Int J Cancer 129: 799-809, 2011.

102. Guo J, Cagatay T, Zhou G, et al: Mutations in the human naked cuticle homolog NKD1 found in colorectal cancer alter Wnt/Dvl/beta-catenin signaling. PLoS One 4: e7982, 2009.

103. Kim SJ, Hwang JA, Ro JY, Lee YS and Chun KH: Galectin-7 is epigenetically-regulated tumor suppressor in gastric cancer. Oncotarget 4: 1461-1471, 2013.

104. Kopitz J, Andre S, von Reitzenstein C, et al: Homodimeric galectin-7 (p53-induced gene 1) is a negative growth regulator for human neuroblastoma cells. Oncogene 22: 6277-6288, 2003.

105. Kobayashi T, Kuroda J, Ashihara E, et al: Galectin-9 exhibits anti-myeloma activity through JNK and p38 MAP kinase pathways. Leukemia 24: 843-850, 2010.

106. Nagy N, Bronckart Y, Camby I, et al: Galectin- 8 expression decreases in cancer compared with normal and dysplastic human colon tissue and acts significantly on human colon cancer cell migration as a suppressor. Gut 50: 392-401, 2002.

107. Yang RY, Hsu DK, Yu L, Ni J and Liu FT: Cell cycle regulation by galectin-12, a new member of the galectin superfamily. J Biol Chem 276: 20252-20260, 2001.

108. Clausse N, van den Brule F, Waltregny D, Garnier F and Castronovo V: Galectin-1 expression in prostate tumorassociated capillary endothelial cells is increased by prostate carcinoma cells and modulates heterotypic cell-cell adhesion. Angiogenesis 3: 317-325, 1999.

109. Hsu YL, Wu CY, Hung JY, Lin YS, Huang MS and Kuo PL: Galectin-1 promotes lung cancer tumor metastasis by potentiating integrin alpha6beta 4 and Notch $1 /$ Jagged 2 signaling pathway. Carcinogenesis 34: 1370-1381, 2013.

110. Hittelet A, Legendre H, Nagy N, et al: Upregulation of galectins- 1 and -3 in human colon cancer and their role in regulating cell migration. Int J Cancer 103: 370-379, 2003.

111. Spano D, Russo R, Di Maso V, et al: Galectin-1 and its involvement in hepatocellular carcinoma aggressiveness. Mol Med 16: $102-115,2010$

112. Jung TY, Jung S, Ryu HH, et al: Role of galectin-1 in migration and invasion of human glioblastoma multiforme cell lines. J Neurosurg 109: 273-284, 2008.

113. Rorive S, Belot N, Decaestecker C, et al: Galectin-1 is highly expressed in human gliomas with relevance for modulation of invasion of tumor astrocytes into the brain parenchyma. Glia 33: 241-255, 2001.

114. Xue X, Lu Z, Tang D, et al: Galectin-1 secreted by activated stellate cells in pancreatic ductal adenocarcinoma stroma promotes proliferation and invasion of pancreatic cancer cells: an in vitro study on the microenvironment of pancreatic ductal adenocarcinoma. Pancreas 40: 832-839, 2011.

115. Kim HJ, Do IG, Jeon HK, et al: Galectin 1 expression is associated with tumor invasion and metastasis in stage IB to IIA cervical cancer. Hum Pathol 44: 62-68, 2013.

116. Barrow $\mathrm{H}$, Guo $\mathrm{X}$, Wandall $\mathrm{HH}$, et al: Serum galectin-2, -4 , and -8 are greatly increased in colon and breast cancer patients and promote cancer cell adhesion to blood vascular endothelium. Clin Cancer Res 17: 7035-7046, 2011.
117. O'Driscoll L, Linehan R, Liang YH, Joyce H, Oglesby I and Clynes M: Galectin-3 expression alters adhesion, motility and invasion in a lung cell line (DLKP), in vitro. Anticancer Res 22: 3117-3125, 2002

118. Kim SJ, Choi IJ, Cheong TC, et al: Galectin-3 increases gastric cancer cell motility by up-regulating fascin-1 expression. Gastroenterology 138: 1035-1045.e2, 2010.

119. Kim SJ, Shin JY, Lee KD, et al: Galectin-3 facilitates cell motility in gastric cancer by up-regulating protease-activated receptor-1 (PAR-1) and matrix metalloproteinase-1 (MMP-1). PLoS One 6: e25103, 2011.

120. Wang Y, Nangia-Makker P, Tait L, et al: Regulation of prostate cancer progression by galectin-3. Am J Pathol 174: 1515-1523, 2009.

121. Debray C, Vereecken P, Belot N, et al: Multifaceted role of galectin-3 on human glioblastoma cell motility. Biochem Biophys Res Commun 325: 1393-1398, 2004.

122. Braeuer RR, Zigler M, Kamiya T, et al: Galectin-3 contributes to melanoma growth and metastasis via regulation of NFAT1 and autotaxin. Cancer Res 72: 5757-5766, 2012.

123. Radosavljevic G, Jovanovic I, Majstorovic I, et al: Deletion of galectin-3 in the host attenuates metastasis of murine melanoma by modulating tumor adhesion and NK cell activity. Clin Exp Metastasis 28: 451-462, 2011.

124. Inufusa $\mathrm{H}$, Nakamura M, Adachi $\mathrm{T}$, et al: Role of galectin-3 in adenocarcinoma liver metastasis. Int J Oncol 19: 913-919, 2001.

125. Bresalier RS, Mazurek N, Sternberg LR, et al: Metastasis of human colon cancer is altered by modifying expression of the beta-galactoside-binding protein galectin 3. Gastroenterology 115: 287-296, 1998.

126. Ellerhorst JA, Stephens LC, Nguyen T and Xu XC: Effects of galectin-3 expression on growth and tumorigenicity of the prostate cancer cell line LNCaP. Prostate 50: 64-70, 2002.

127. Demers M, Biron-Pain K, Hebert J, Lamarre A, Magnaldo T and St-Pierre Y: Galectin-7 in lymphoma: elevated expression in human lymphoid malignancies and decreased lymphoma dissemination by antisense strategies in experimental model. Cancer Res 67: 2824-2829, 2007.

128. Demers M, Magnaldo T and St-Pierre Y: A novel function for galectin-7: promoting tumorigenesis by up-regulating MMP-9 gene expression. Cancer Res 65: 5205-5210, 2005.

129. Moisan S, Demers M, Mercier J, Magnaldo T, Potworowski EF and St-Pierre Y: Upregulation of galectin-7 in murine lymphoma cells is associated with progression toward an aggressive phenotype. Leukemia 17: 751-759, 2003.

130. Park JE, Chang WY and Cho M: Induction of matrix metalloproteinase- 9 by galectin-7 through p38 MAPK signaling in HeLa human cervical epithelial adenocarcinoma cells. Oncol Rep 22: 1373-1379, 2009.

131. Camby I, Belot N, Rorive S, et al: Galectins are differentially expressed in supratentorial pilocytic astrocytomas, astrocytomas, anaplastic astrocytomas and glioblastomas, and significantly modulate tumor astrocyte migration. Brain Pathol 11: 12-26, 2001.

132. Kasamatsu A, Uzawa K, Nakashima D, et al: Galectin-9 as a regulator of cellular adhesion in human oral squamous cell carcinoma cell lines. Int J Mol Med 16: 269-273, 2005.

133. Yamauchi A, Kontani K, Kihara M, Nishi N, Yokomise H and Hirashima M: Galectin-9, a novel prognostic factor with antimetastatic potential in breast cancer. Breast J 12: S196-S200, 2006.

134. Zhang F, Zheng M, Qu Y, et al: Different roles of galectin-9 isoforms in modulating E-selectin expression and adhesion function in LoVo colon carcinoma cells. Mol Biol Rep 36: 823-830, 2009.

135. Zhang F, Zheng MH, Qu Y, et al: Galectin-9 isoforms influence the adhesion between colon carcinoma LoVo cells and human umbilical vein endothelial cells in vitro by regulating the expression of E-selectin in LoVo cells. Zhonghua Zhong Liu Za Zhi 31: 95-98, 2009 (In Chinese).

136. Nobumoto A, Nagahara K, Oomizu S, et al: Galectin-9 suppresses tumor metastasis by blocking adhesion to endothelium and extracellular matrices. Glycobiology 18: 735-744, 2008.

137. Le Mercier M, Mathieu V, Haibe-Kains B, et al: Knocking down galectin 1 in human hs683 glioblastoma cells impairs both angiogenesis and endoplasmic reticulum stress responses. J Neuropathol Exp Neurol 67: 456-469, 2008.

138. Ito K, Scott SA, Cutler S, et al: Thiodigalactoside inhibits murine cancers by concurrently blocking effects of galectin-1 on immune dysregulation, angiogenesis and protection against oxidative stress. Angiogenesis 14: 293-307, 2011. 
139. Mourad-Zeidan AA, Melnikova VO, Wang H, Raz A and Bar-Eli M: Expression profiling of Galectin-3-depleted melanoma cells reveals its major role in melanoma cell plasticity and vasculogenic mimicry. Am J Pathol 173: 1839-1852, 2008.

140. Daroqui CM, Ilarregui JM, Rubinstein N, et al: Regulation of galectin-1 expression by transforming growth factor betal in metastatic mammary adenocarcinoma cells: implications for tumor-immune escape. Cancer Immunol Immunother 56: 491-499, 2007.

141. He J and Baum LG: Endothelial cell expression of galectin-1 induced by prostate cancer cells inhibits T-cell transendothelial migration. Lab Invest 86: 578-590, 2006.

142. Tang D, Yuan Z, Xue X, et al: High expression of galectin-1 in pancreatic stellate cells plays a role in the development and maintenance of an immunosuppressive microenvironment in pancreatic cancer. Int J Cancer 130: 2337-2348, 2012

143. Peng W, Wang HY, Miyahara Y, Peng G and Wang RF: Tumorassociated galectin-3 modulates the function of tumor-reactive T cells. Cancer Res 68: 7228-7236, 2008.

144. Troncoso MF, Elola MT, Croci DO and Rabinovich GA Integrating structure and function of 'tandem-repeat' galectins. Front Biosci (Schol Ed) 4: 864-887, 2012.

145. Scott K and Weinberg C: Galectin-1: a bifunctional regulator of cellular proliferation. Glycoconj J 19: 467-477, 2004

146. Haudek KC, Spronk KJ, Voss PG, Patterson RJ, Wang JL and Arnoys EJ: Dynamics of galectin-3 in the nucleus and cytoplasm. Biochim Biophys Acta 1800: 181-189, 2010.

147. Shimura T, Takenaka Y, Fukumori T, et al: Implication of galectin-3 in Wnt signaling. Cancer Res 65: 3535-3537, 2005.

148. Ackerman SJ, Liu L, Kwatia MA, et al: Charcot-Leyden crystal protein (galectin-10) is not a dual function galectin with lysophospholipase activity but binds a lysophospholipase inhibitor in a novel structural fashion. J Biol Chem 277: 14859-14868, 2002.

149. Swaminathan GJ, Leonidas DD, Savage MP, Ackerman SJ and Acharya KR: Selective recognition of mannose by the human eosinophil Charcot-Leyden crystal protein (galectin-10): a crystallographic study at 1.8 A resolution. Biochemistry 38 : 13837-13843, 1999.

150. Satelli A, Rao PS, Gupta PK, Lockman PR, Srivenugopal KS and Rao US: Varied expression and localization of multiple galectins in different cancer cell lines. Oncol Rep 19: 587-594, 2008.

151. Mbeunkui F, Metge BJ, Shevde LA and Pannell LK: Identification of differentially secreted biomarkers using LC-MS/MS in isogenic cell lines representing a progression of breast cancer. J Proteome Res 6: 2993-3002, 2007.

152. Khaldoyanidi SK, Glinsky VV, Sikora L, et al: MDA-MB-435 human breast carcinoma cell homo- and heterotypic adhesion under flow conditions is mediated in part by ThomsenFriedenreich antigen-galectin-3 interactions. J Biol Chem 278 4127-4134, 2003

153. Inohara $\mathrm{H}$ and Raz A: Effects of natural complex carbohydrate (citrus pectin) on murine melanoma cell properties related to galectin-3 functions. Glycoconj J 11: 527-532, 1994.

154. Pienta KJ, Naik H, Akhtar A, et al: Inhibition of spontaneous metastasis in a rat prostate cancer model by oral administration of modified citrus pectin. J Natl Cancer Inst 87: 348-353, 1995.

155. Nangia-Makker P, Hogan V, Honjo Y, et al: Inhibition of human cancer cell growth and metastasis in nude mice by oral intake of modified citrus pectin. J Natl Cancer Inst 94: 1854-1862, 2002.

156. Dings RP, Miller MC, Nesmelova I, et al: Antitumor agent calixarene 0118 targets human galectin-1 as an allosteric inhibitor of carbohydrate binding. J Med Chem 55: 5121-5129, 2012.

157. Chiariotti L, Berlingieri MT, Battaglia C, et al: Expression of galectin-1 in normal human thyroid gland and in differentiated and poorly differentiated thyroid tumors. Int J Cancer 64 $171-175,1995$

158. Ellerhorst J, Nguyen T, Cooper DN, Lotan D and Lotan R Differential expression of endogenous galectin-1 and galectin-3 in human prostate cancer cell lines and effects of overexpressing galectin-1 on cell phenotype. Int J Oncol 14: 217-224, 1999.

159. Laderach DJ, Gentilini LD, Giribaldi L, et al: A unique galectin signature in human prostate cancer progression suggests galectin-1 as a key target for treatment of advanced disease. Cancer Res 73: 86-96, 2013.
160. Jung EJ, Moon HG, Cho BI, et al: Galectin-1 expression in cancer-associated stromal cells correlates tumor invasiveness and tumor progression in breast cancer. Int J Cancer 120 2331-2338, 2007.

161. Dalotto-Moreno T, Croci DO, Cerliani JP, et al: Targeting galectin-1 overcomes breast cancer-associated immunosuppression and prevents metastatic disease. Cancer Res 73 $1107-1117,2013$

162. Zhao XY, Chen TT, Xia L, et al: Hypoxia inducible factor-1 mediates expression of galectin-1: the potential role in migration/invasion of colorectal cancer cells. Carcinogenesis 31: 1367-1375, 2010 .

163. Camby I, Decaestecker C, Lefranc F, Kaltner H, Gabius HJ and Kiss R: Galectin-1 knocking down in human U87 glioblastoma cells alters their gene expression pattern. Biochem Biophys Res Commun 335: 27-35, 2005.

164. Strik HM, Schmidt K, Lingor P, et al: Galectin-1 expression in human glioma cells: modulation by ionizing radiation and effects on tumor cell proliferation and migration. Oncol Rep 18: 483-488, 2007.

165. Le Mercier M, Lefranc F, Mijatovic T, et al: Evidence of galectin-1 involvement in glioma chemoresistance. Toxicol Appl Pharmacol 229: 172-183, 2008.

166. Tinari N, Kuwabara I, Huflejt ME, Shen PF, Iacobelli S and Liu FT: Glycoprotein 90K/MAC-2BP interacts with galectin-1 and mediates galectin-1-induced cell aggregation. Int $\mathbf{J}$ Cancer 91: 167-172, 2001.

167. Wu KL, Huang EY, Jhu EW, et al: Overexpression of galectin-3 enhances migration of colon cancer cells related to activation of the K-Ras-Raf-Erk1/2 pathway. J Gastroenterol 48: 350-359, 2013.

168. Honjo $\mathrm{Y}$, Nangia-Makker $\mathrm{P}$, Inohara $\mathrm{H}$ and $\mathrm{Raz} \mathrm{A}$ : Down-regulation of galectin-3 suppresses tumorigenicity of human breast carcinoma cells. Clin Cancer Res 7: 661-668, 2001.

169. Shekhar MP, Nangia-Makker P, Tait L, Miller F and Raz A: Alterations in galectin-3 expression and distribution correlate with breast cancer progression: functional analysis of galectin-3 in breast epithelial-endothelial interactions. Am J Pathol 165: 1931-1941, 2004.

170. Baptiste TA, James A, Saria M and Ochieng J: Mechano-transduction mediated secretion and uptake of galectin-3 in breast carcinoma cells: implications in the extracellular functions of the lectin. Exp Cell Res 313: 652-664, 2007.

171. Van den Brule FA, Waltregny D, Liu FT and Castronovo V: Alteration of the cytoplasmic/nuclear expression pattern of galectin-3 correlates with prostate carcinoma progression. Int J Cancer 89: 361-367, 2000

172. Yoshii T, Inohara H, Takenaka Y, et al: Galectin-3 maintains the transformed phenotype of thyroid papillary carcinoma cells. Int J Oncol 18: 787-792, 2001.

173. Takenaka Y, Inohara H, Yoshii T, et al: Malignant transformation of thyroid follicular cells by galectin-3. Cancer Lett 195: $111-119,2003$.

174. Shankar J, Wiseman SM, Meng F, et al: Coordinated expression of galectin-3 and caveolin-1 in thyroid cancer. J Pathol 228: 56-66, 2012

175. Li W, Jian-jun W, Xue-Feng Z and Feng Z: CD133(+) human pulmonary adenocarcinoma cells induce apoptosis of CD8(+) T cells by highly expressed galectin-3. Clin Invest Med 33: E44-E53, 2010.

176. Clark MC, Pang M, Hsu DK, et al: Galectin-3 binds to CD45 on diffuse large B-cell lymphoma cells to regulate susceptibility to cell death. Blood 120: 4635-4644, 2012.

177. Srinivasan N, Bane SM, Ahire SD, Ingle AD and Kalraiya RD Poly N-acetyllactosamine substitutions on $\mathrm{N}$ - and not O-oligosaccharides or Thomsen-Friedenreich antigen facilitate lung specific metastasis of melanoma cells via galectin-3. Glycoconj J 26: 445-456, 2009.

178. Wang YG, Kim SJ, Baek JH, Lee HW, Jeong SY and Chun KH: Galectin-3 increases the motility of mouse melanoma cells by regulating matrix metalloproteinase-1 expression. Exp Mol Med 44: 387-393, 2012.

179. Oishi T, Itamochi H, Kigawa J, et al: Galectin-3 may contribute to Cisplatin resistance in clear cell carcinoma of the ovary. Int J Gynecol Cancer 17: 1040-1046, 2007.

180. Kim MK, Sung CO, Do IG, et al: Overexpression of Galectin-3 and its clinical significance in ovarian carcinoma. Int J Clin Oncol 16: 352-358, 2011.

181. Merlin J, Stechly L, de Beauce S, et al: Galectin-3 regulates MUC1 and EGFR cellular distribution and EGFR downstream pathways in pancreatic cancer cells. Oncogene 30: 2514-2525, 2011 
182. Kobayashi T, Shimura T, Yajima T, et al: Transient silencing of galectin-3 expression promotes both in vitro and in vivo druginduced apoptosis of human pancreatic carcinoma cells. Clin Exp Metastasis 28: 367-376, 2011

183. Ideo H, Seko A and Yamashita K: Galectin- 4 binds to sulfated glycosphingolipids and carcinoembryonic antigen in patches on the cell surface of human colon adenocarcinoma cells. J Biol Chem 280: 4730-4737, 2005.

184. Kuroda J, Yamamoto M, Nagoshi H, et al: Targeting activating transcription factor 3 by Galectin- 9 induces apoptosis and overcomes various types of treatment resistance in chronic myelogenous leukemia. Mol Cancer Res 8: 994-1001, 2010.

185. Gonzalez MM, Yoshizaki L, Wolfenstein-Todel C and Fink NE: Isolation of galectin-1 from human platelets: its interaction with actin. Protein J 31: 8-14, 2012.

186. Pace KE, Lee C, Stewart PL and Baum LG: Restricted receptor segregation into membrane microdomains occurs on human $\mathrm{T}$ cells during apoptosis induced by galectin-1. J Immunol 163 : 3801-3811, 1999.

187. Liu L, Sakai T, Sano N and Fukui K: Nucling mediates apoptosis by inhibiting expression of galectin-3 through interference with nuclear factor kappaB signalling. Biochem J 380: 31-41, 2004

188. Seve AP, Felin M, Doyennette-Moyne MA, Sahraoui T, Aubery $\mathrm{M}$ and Hubert J: Evidence for a lactose-mediated association between two nuclear carbohydrate-binding proteins. Glycobiology 3: 23-30, 1993.
189. Paron I, Scaloni A, Pines A, et al: Nuclear localization of Galectin-3 in transformed thyroid cells: a role in transcriptional regulation. Biochem Biophys Res Commun 302: 545-553, 2003.

190. Vito P, Pellegrini L, Guiet C and D'Adamio L: Cloning of AIP1, a novel protein that associates with the apoptosis-linked gene ALG-2 in a $\mathrm{Ca}^{2+}$-dependent reaction. J Biol Chem 274: 1533-1540, 1999.

191. Missotten M, Nichols A, Rieger K and Sadoul R: Alix, a novel mouse protein undergoing calcium-dependent interaction with the apoptosis-linked-gene 2 (ALG-2) protein. Cell Death Differ 6: 124-129, 1999.

192. Liu FT, Patterson RJ and Wang JL: Intracellular functions of galectins. Biochim Biophys Acta 1572: 263-273, 2002.

193. Menon RP, Strom M and Hughes RC: Interaction of a novel cysteine and histidine-rich cytoplasmic protein with galectin-3 in a carbohydrate-independent manner. FEBS Lett 470: 227-231, 2000.

194. Bawumia S, Barboni EA, Menon RP and Hughes RC: Specificity of interactions of galectin-3 with Chrp, a cysteineand histidine-rich cytoplasmic protein. Biochimie 85: 189-194, 2003.

195. Inagaki Y, Higashi K, Kushida M, et al: Hepatocyte growth factor suppresses profibrogenic signal transduction via nuclear export of Smad3 with galectin-7. Gastroenterology 134: 1180-1190, 2008. 